\title{
Structure and Mechanical Properties of WE43 Prepared by Powder Metallurgy Route
}

Drahomir Dvorsky ${ }^{1}$, Jiri Kubasek ${ }^{1}$, Dalibor Vojtech ${ }^{1}$, Miroslav Cavojsky ${ }^{2}$

${ }^{1}$ Faculty of chemical technology, Department of metals and corrosion engineering, University of chemistry and technology Prague, Technická 516628 Praha 6 - Dejvice, Czech Republic, E-mail: dvorskyd@ vscht.cz, Jiri.Kubasek@vscht.cz, Dalibor.Vojtech@vscht.cz

${ }^{2}$ Institute of Materials and Machine Mechanics SAS, Slovak Academy of Sciences, Dúbravská cesta 9, 84513 Bratislava, Slovak Republic

Rare earth elements in magnesium alloy enhance mechanical properties, corrosion resistance, and heat stability up to $300{ }^{\circ} \mathrm{C}$. Those enhancements with low density of magnesium determine this alloy for aviation and automotive industry. Magnesium alloys are also considered as materials for biodegradable implants. In this field there are required good mechanical properties and fair corrosion rate. In this work, WE43 alloy prepared by powder metallurgy with different conditions of sub-processes is prepared. Milling, cold uniaxial pressing, spark plasma sintering (SPS) and extrusion processes are used for sample preparations. Structure and mechanical properties of prepared materials are characterized.

Keywords: WE43, powder metallurgy, milling, extrusion.

\section{Aknowledgement}

Authors wish to thank the Czech Science Foundation (project no. P108/12/G043) and specific university research (MSMT No 20-SVV/2016) for the financial support of this research.

\section{References}

[1] T. RZYCHOŃ, A. K.. (2007). Microstructure of WE43 casting magnesium alloy. In: Journal of achievements in materials and manufacturing engineering, 21 (1).

[2] KUBÁSEK, J.; VOJTĚCH, D. (2014). Structural, mechanical and corrosion study on possible biodegradable magnesium alloys. In: METAL 2014 - 23rd International Conference on Metallurgy and Materials, Conference Proceedings, pp. 1097-1102.

[3] KUBÁSEK, J.; VOJTĚCH, D. (2013) Structural and corrosion characterization of biodegradable Mg-RE (RE=Gd, Y, Nd) alloys. Transactions of Nonferrous Metals Society of China 2013, 23 (5), 1215-1225.

[4] KUBÁSEK, J.; VOJTĚCH, D.; ČAPEK, J. (2012). Properties of Biodegradable Alloys Usable for Medical Purposes. Acta Physica Polonica A, 122 (3), 520-523.

[5] QIAN, M.; HILDEBRAND, Z. C. G.; STJOHN, D. H. (2009). The Loss of Dissolved Zirconium in ZirconiumRefined Magnesium Alloys after Remelting. Metall and Mat Trans A, 40, 2470-2479.

[6] ČAPEK, J.; VOJTĚCH, D. (2015). Powder Metallurgical Techniques for Fabrication of Biomaterials. Manufacturing Technology, 15 (6), 964-969.

[7] ZHENG, Y. F.; GU, X. N.; WITTE, F. (2014). Biodegradable metals. Materials Science and Engineering: R: Reports, 77 (0), 1-34.

[8] VOJTĚCH, D., B. B., VERNER, J., ŠERÁK, J. (2004). Rychlé chlazení kovů - význam, technologie a využití. Chemické Listy, 98, 180-184.

[9] DVORSKÝ, D.; KUBÁSEK, J.; VOJTĚCH, D. (2015). Hydroxyapatite in Materials for Medical Applications Manufacturing Technology, 15 (6), 969-973.

[10] HAO, L.; LU, Y.; SATO, H.; ASANUMA, H.; GUO, J. (2013). Analysis on energy transfer during mechanical coating and ball milling-Supported by electric power measurement in planetary ball mill. International Journal of Mineral Processing, 121 (0), 51-58.

[11] DVORSKÝ, D.; KUBÁSEK, J.; VOJTĚCH, D.; PRU゚ŠA, F.; NOVÁ, K. (2016). Preparation of WE43 using powder metallurgy route. Manufacturing Technology, 16 (4), 680-687.

[12] HAO, L.; LU, Y.; SATO, H.; ASANUMA, H. (2012). Fabrication of zinc coatings on alumina balls from zinc powder by mechanical coating technique and the process analysis. Powder Technology, 228 (0), 377-384. 
[13] PRŮŠA, F.; VOJTĚCH, D.; BLÁHOVÁ, M.; MICHALCOVÁ, A.; KUBATÍK, T. F.; ČÍŽEK, J. (2015). Structure and mechanical properties of $\mathrm{Al}-\mathrm{Si}-\mathrm{Fe}$ alloys prepared by short-term mechanical alloying and spark plasma sintering. Materials \& Design, 75, 65-75.

[14] KUBÁSEK, J.; VOJTĚCH, D.; DVORSKÝ, D. (2015). Preparation and Properties of Composite Materials with Magnesium Matrix and Hydroxyapatite Reinforcement Manufacturing Technology, 15 (4).

[15] YIN, D. L.; WANG, J. T.; LIU, J. Q.; ZHAO, X. (2009). On tension-compression yield asymmetry in an extruded Mg-3Al-1Zn alloy. Journal of Alloys and Compounds, 478 (1-2), 789-795.

[16] WU, Y. P.; ZHANG, X. M.; DENG, Y. L.; TANG, C. P.; ZHONG, Y. Y. (2015). Effect of compression conditions on the microstructure and texture of a Mg-RE alloy. Materials Science and Engineering: A, 644, 152-158.

\section{Paper number: M2016166}

Copyright $\odot$ 2016. Published by Manufacturing Technology. All rights reserved. 